Julia Stepnowska

Uniwersytet Gdański

stepnowska.julia@gmail.com; ORCID: 0000-0003-3832-9357

\title{
Due Diligence and the Art Market. Assessing the Impact of the 1995 UNIDROIT Convention on Stolen or Illegally Exported Cultural Objects
}

\author{
http://dx.doi.org/10.12775/SIT.2018.020
}

Art trade, ever since the $17^{\text {th }}$ century ${ }^{1}$, has been a matter of sustaining cross-national relations. With the development of the multinational approach to cultural cooperation in a broad sense and the global expansion of art business entities, fostering the increase of art value awareness, the trafficking in cultural objects has become subject to the developing international restrictions on transportation and trade regulations. The protection of cultural objects bears significance especially in the times of increasing armed conflicts and the loss of cultural identity due to the omnipresent globalisation of the $21^{\text {st }}$ century. On the other hand, it was already in the post-WWI political circumstances that the idea of a "world" heritage was coined ${ }^{2}$. It was one of the aims of the League of Nations to provide a space for a cross-national dialogue on universal values such as the protection of common cultural heritage.

${ }^{1}$ Cf. P. Hook, Rogues' Gallery: A History of Art and its Dealers, London, 2017.

2 M.A. Elliott, V. Schmutz, World heritage, "The Wiley-Blackwell Encyclopedia of Globalization” 2017, Vol. 1-2, p. 1, doi: 10.1002/9780470670590.wbeog 823.pub2. 
The International Institute for the Unification of Private Law (UNIDROIT) was formed under the auspices of the League of Nations and the preservation and protection of cultural heritage has always been one of the pillars of its activity. The Convention on Stolen or Illegally Exported Cultural Objects was drafted by UNIDROIT as a response to the questions on levelling public and private law with regards to the provisions of licit cultural object transport and, subsequently, trade, especially in the scope of establishing a common understanding of the term of a bona fide purchaser, protected in many legal systems. The main gap in the UNESCO Convention on the Means of Prohibiting and Preventing the Illicit Import, Export and Transfer of Ownership of Cultural Property of 1970, the first document regulating this scope in an international perspective, did not fill the gap of establishing common, detailed grounds for such notions as the good faith acquisition and, inter alia, the notion of due diligence, present in various legal systems in an incompatible form. Since UNESCO does not hold authority in the instance of national law, it could itself forecast it would not provide an ultimate resolution, hence the relegation of establishing common legal grounds to UNIDROIT.

\section{The 1995 Convention and its Gains}

The Institute, founded in 1926 in Rome, was established, according to its current Statute, incorporating the amendment to Article 6(1) which entered into force on 26 March 1993, to "harmonise" and "coordinate" the "private law of States and of groups of States, and to prepare gradually for the adoption by the various States of uniform rules of private law." This aim is executed by the means of drafting laws and conventions to establish uniform internal law, as well as agreements to foster international relations in the private law area. To this end, UNIDROIT has played a critical role as a facilitator of cross-national legal framework for the field of e.g. cultural property, international sales, or international will. The main work of the Institute concerning the area of cultural property is the 1995 Convention on Stolen or Illegally Exported Cultural Objects. With regards to the 
efforts of the Institute to "undertake studies in comparative private law" as well as "take an interest in projects already undertaken in any of these fields by other institutions with which it may maintain relations as necessary" or "organise conferences and publish works which the Institute considers worthy of wide circulation," the Institute has established the 1995 UNDROIT Convention Academic Project (UCAP) to facilitate the study and research exchange by the means of publishing studies and organising conferences.

The main goal of the 1995 Convention was to, primarily, level private and public law in the pursuit of establishing a framework for cross-national cooperation in the field of returning stolen or illegally exported cultural objects. First and foremost, the Convention aimed at establishing the rule of a duty to restitute a looted cultural object and return an illegally exported good, as well as regulate the issue of the bona fide purchaser and its conflicting interpretation in various legal systems, providing a flexible time limit for restitution claims, and the case of compensation for the possessor exercising due diligence, as well as providing an outline of means for exercising it in a practical sense.

The Convention established a clear division of two interchangeably utilised terms, i.e. restitution and return, and specifies the circumstances under which a given case falls under the term of restitution or return:

"This Convention applies to claims of an international character for:

(a) the restitution of stolen cultural objects;

(b) the return of cultural objects removed from the territory of a Contracting State contrary to its law regulating the export of cultural objects for the purpose of protecting its cultural heritage (hereinafter 'illegally exported cultural objects')"3.

The universal outlook on the case of preserving and protecting cultural heritage guiding the authors of the Convention, is reflected in the unification of the rule of the "absolute duty" 4 to return

${ }^{3}$ Art. 1 of the Convention.

${ }^{4}$ W. Kowalski, The road to the 1995 UNIDROIT Convention and its basic solutions, "Santander Art and Culture Law Review" 2015, Vol. 1, p. 67, doi: 10.4467/2450050XSR.15.001.3769. 
and restitute. This universal approach is reflected in the section devoted to time limitations governing the return or restitution. The time limitations set forth in the case of stolen objects restitution, address the circumstances of the theft and the object itself. In general terms, "any claim for restitution shall be brought within a period of three years from the time when the claimant knew the location of the cultural object and the identity of its possessor" this provision triggers a question on the solution provided in the case when the condition is only partially met, i.e. the location is known but not the possessor's identity. However, as it may be assumed, the final part of this point applies to such situations, as it is stated that restitution is possible „in any case within a period of fifty years from the time of the theft." The Convention sets forth the measures applicable in regarding to particular objects, i.e. the time limitations for restitution claims, provided in the previously mentioned chapter, depend on whether the object in question forms an integral part of one of the following categories:

- Identified monument,

- Archaeological site,

- Public collection.

Pursuant to the Convention, in the case of the following objects, only the latter applies, i.e. "a period of three years from the time when the claimant knew the location of the cultural object and the identity of its possessor." Nevertheless, any Contracting State may declare that a claim is subject to a time limitation of 75 years or such longer period as is provided in its law. The main success of the Convention is establishing a fairly extensive and flexible, as stated in Paragraph 5, timeframe for claims, as opposed to the preceding documents. When discussing the approach to quite "agile" jurisdictional rules set forth in the Convention, it is noteworthy that the ratification of the Convention implies a preference of arbitration since it enables the subject-matter experts to act as arbitrators ${ }^{5}$,

${ }^{5}$ M. Schneider, UNIDROIT Convention on Stolen or Illegally Exported Cultural Objects: Explanatory Report/Convention d'UNIDROIT sur les biens culturels volés ou illicitement exportés: rapport explicatif, "Uniform Law Review" 2001, Vol. 6, Issue 3, p. 544, doi: https://doi.org/10.1093/ulr/6.3.476. 
thus eliminates the factor of incompetency when settling a dispute ${ }^{6}$ and secures the know-how of art business professionals thanks to its confidential nature. In such complex cases, the role of ADR needs to be stressed as it permits the resolution of international art-law dispute that concerns different jurisdictions in a swift manner ${ }^{7}$. Moreover, the Convention addresses the question of fair compensation paid to the possessor. Although the case of the return of an illegally exported object clearly points at the claimant as the State party, thus the State is obliged to pay the compensation to the possessor, the issue of who incurs the cost in the case of restitution is not clear. Moreover, the Convention is listed as one of key references for establishing due diligence measures on the part of the owner in the literature ${ }^{8}$.

\section{Due diligence}

The vigilance of persons involved in the provenance of works in circulation due to varying circumstances is a key aspect in fighting illicit trafficking in works of art.*

The above statement introduces the key to establishing the circumstances of a bona fide purchase, i.e. exercising due diligence. The art

* M. Cornu, Engaging the European Art Market in the fight against the illicit trafficking of cultural property. Study for the capacity-building conference, 20-21 March 2018. Fighting Illicit Trafficking in Cultural Objects, Searching for Provenance and Exercising Due Diligence in the European Union, 2017, p. 2, available at: http://www.unesco.org/new/fileadmin/MULTIMEDIA/HQ/CLT/ images/630X300/Study_Prof_Cornu_EN_00.pdf (access: 26.04.2018).

${ }^{6}$ V.K. Reeves, Establishing Authenticity in French Law, in: R.D. Spencer (ed.), The Expert versus the Object: Judging Fakes and False Attributions in the Visual Arts, New York 2004, p. 228.

7 A.L. Bandle, S. Theurich, Alternative Dispute Resolution and Art-Law A New Research Project of the Geneva Art-Law Centre, "Journal of International Commercial law and Technology” 2011, Vol. 6, Issue 1, p.30.

${ }^{8}$ Cf. S. Giroud, Ch. Boudry, Art Lawyer's Due Diligence Obligations: A Difficult Equilibrium between Law and Ethics, "International Journal of Cultural Property” 2015, Vol. 22, Issue 2-3, p. 403. doi: 10.1017/S094073911500019. 
world in this respect, comprises not only of art market professionals, but also the clients on the market. When exercising due diligence ${ }^{9}$, pursuant to Article 4 of the Convention, the possessor (the buyer) is bound to have consulted any "reasonably accessible register of stolen cultural object" and "any other accessible documentation." The conditions set forth in the Convention are by no means reflecting the case of private collections, when the owner might have obtained an object by inheritance, since registering and documenting such collections is a fairly rare phenomenon, especially when not previously valuated. Moreover, in want of a globally "accessible" register ${ }^{10}$ encompassing the information on missing cultural objects, the possessor may not meet the criteria unless consulting an expert. On the other hand, art business entities in emerging art markets do not provide in-depth subject matter knowledge for foreign works, therefore, a trustworthy source of information may be not available at the country where the objects are located, i.e. the pursuit of a fair valuation may also lead to exporting an object of unknown provenance abroad. It is worth to mention that the gaps between economic conditions in the different zones in Europe was one of the main political contexts in the work on completing the Convention ${ }^{11}$. The issue of determining the ultimate solution to establishing due diligence proves to be the most controversial and tangible reflection of the problem of approaching bona fide purchasers. Since due diligence is treated as a key marker of good faith, it is essential to provide a clear, yet flexible definition encompassing the differences on markets.

As per the guidelines set forth in the Convention, due diligence is, inter alia, linked to consulting looted art registers. The main issue in this case is the lack of subject matter knowledge of the possessor to describe the object in proper terms when requesting

9 Cf. K. Zalasińska, Dobra wiara jako przesłanka ochrony nabywców kradzionych dzieł sztuki. Wybrane zagadnienia, "Palestra" 2010, Issue 5-6, p. 53, available at: http://palestra.pl/upload/14/30/20/1430209222_.pdf (access: 28.04.2018).

${ }^{10}$ It is worth mentioning that the fairly trustworthy registers demand a payment for their service, hence the omission of this step in some cases.

${ }^{11}$ W. Kowalski, op.cit., p. 78. 
for a (paid) expert opinion. While the case of a figurative painting, if not restored in the meantime, is fairly accessible, the case of undefined objects of craftsmanship or everyday use requires the knowledge of the material used, the time of the creation, possible provenance documents. The process of establishing the provenance of such objects, especially when of distant cultural affiliation. Due diligence is also crucial in the assessment of money-laundering risk in art transactions. The "Know Your Client" rule observed by art business entities required for the entity to conduct an extensive research on the possessor being a potential client. It is pursuant to Art. 10 of the Directive 2014/60/EU of the European Parliament and of the Council of 15 May 2014 on the return of cultural objects unlawfully removed from the territory of a Member State, that the compensation is also dependent on meeting the due diligence condition ${ }^{12}$.

The measures according to which due diligence exists and is interpreted in various legal systems is not universal. When discussing the implementation of international agreements, the guidelines for exercising vigilance need to be unified and set forth in a tangible manner. Pursuant to Art. 4 of the 1995 UNIDROIT Convention, the "care and attention" exercised by the possessor of the object is assessed in a cross-reference to "all the circumstances of the acquisition, including the character of the parties, the price paid, whether the possessor consulted any reasonably accessible register of stolen cultural objects, and any other relevant information and documentation which it could reasonably have obtained, and whether the possessor consulted accessible agencies or took any other step that a reasonable person would have taken in the circumstances."

Although art professionals use the support of registers, the initial stage of providing data to the request may be an obstacle to laymen bearing in mind the caveat emptor principle. Since the

12 "Where return of the object is ordered, the competent court in the requested Member State shall award the possessor fair compensation according to the circumstances of the case, provided that the possessor demonstrates that he exercised due care and attention in acquiring the object”. 
request comprises of providing the information on mediums used or the provenance (a term that may not clear to non-native English speakers), it is essential to possess basic knowledge of the object which might prove to cause issues in the case of many private collections. Consulting databases is listed in the requirement as a specific point, however, when executing due diligence on the initial level, i.e. realising the artistic value of a given object, apart from consulting an art market professional ${ }^{13}$, would be consulting a catalogue raisonné devoted to the work of a given artist (especially in the case of painting, drawing, lithograph, engraving, etc.).

While discussing the duty to exercise due diligence on the part of an art professional, it is worth to mention that various legal systems approach this question in a multitude of ways. Swiss and Dutch art-related law provides a set of rules pertaining to establishing the obligation of exercising due diligence, in a fairly structured way, as compared to other systems. The aim to confer and unify due diligence measures should play a key role in the process of implementing international agreements since it is the vigilance of the actors involved in art transactions that plays a key role in ascertaining authenticity, ownership, and provenance of a given cultural good $^{14}$. These factors influence the assessment of good faith and since the purchaser's good faith is protected in most civil law countries, even if stolen ${ }^{15}$, it is essential to examine the tangibility and applicability of guidelines for measuring diligence.

\subsection{Price and value}

The question of the "price paid" as a condition listed in assessing due diligence remains fairly open as to what extent (and to what

${ }^{13}$ It is worth to mention that such experts do not fall under any legal category.

${ }^{14}$ S. Giroud, Ch. Boudry, op.cit.

${ }^{15}$ For instance, in France, Germany, Austria, and Switzerland; Cf. M.A. Renold, Stolen Art: The Ubiquitous Question of Good Faith, in: Resolution of Cultural Property Disputes, edited by The International Bureau of the Permanent Court of Arbitration, The Hague 2013, p. 251-63. 
financial thresholds) would this provision apply, as well as how the financial and artistic value impact the review of due diligence measures. The artistic value of an object influences its classification as far as export or import restrictions are concerned: "The provisions of Articles 34 and 35 shall not preclude prohibitions or restrictions on imports, exports or goods in transit justified on grounds of public morality, public policy or public security; the protection of health and life of humans, animals or plants; the protection of national treasures possessing artistic, historic or archaeological value"16.

The question of price is not only linked to established ranges for a given object to be covered by the regulation ${ }^{17}$ but may also reflect the artistic value, despite its intangible nature. Provenance plays a key role not only in the diligent research required by the Convention, but also in establishing the financial value of a work. The place of a given piece in the work of a given author, the previous exhibition or ownership history are key markers of value. From a legal perspective, provenance research is of particular interest to art. market professionals in the face of following the artist resale right (droit de suite). Establishing authorship as part of the research provides a solid ground for denial or acceptance of the right to a resale fee. When establishing provenance and value, despite the development of Artificial Intelligence tools facilitating the research on e.g. authenticity ${ }^{18}$, the role of art experts is undoubtedly critical in provenance research, thus consulting a professional reflects the execution of due diligence by the possessor. However, as in many emerging economies, the art market is mainly local and complex cases may need to be addressed abroad.

${ }^{16}$ The Treaty on the Functioning of the European Union, Article 36 (e.g. Article 30 TEC).

17 The cultural objects in categories A. 1 to A. 15 are covered by this provision only if their value corresponds to, or exceeds, the financial thresholds under B. Council Regulation (EC) No 116/2009 of 18 December 2008 on the export of cultural goods.

${ }^{18}$ Cf. A. Elgammal, Y. Kang, M.D. Leeuw, Picasso, Matisse, or a Fake? Automated Analysis of Drawings at the Stroke Level for Attribution and Authentication, 2017, available at: https://arxiv.org/pdf/1711.03536.pdf (access: 28.04.2018). 


\section{Ratifying the Convention}

The vision of ratifying the UNIDROIT Convention has caused a stir in the art world. The "source" countries and the "market" countries have presented a significantly incoherent approach to the idea of ratifying the agreement ${ }^{19}$. Eleven countries have ratified the agreement ${ }^{20}$, with only one, i.e. Italy, considered to be an actor on the art market with a significant turnover ${ }^{21}$ (as of 2002). The bias on the part of the "market" countries and the somewhat welcoming approach of the "source" countries at the turn of the centuries is also linked to the political and economic inequality between the mature and emerging economies. ${ }^{22}$ A significant number of accusations on the part of art market professionals was caused by a biased understanding of the provisions that appeared to be too far-reaching and inadequate. In 2000, when France was considering to ratify the Convention ${ }^{23}$, the media supported the critical approach and discouraged the state to validate the agreement ${ }^{24}$. While art experts claimed that ratifying the Convention would "destroy" the trade in art, experts in cultural heritage law supported the process of validating the agreement ${ }^{25}$. Since the year 2000 brought new regulations to the art market in France, e.g. the liberalisation

${ }^{19}$ Cf. F. Fiorentini, A legal pluralist approach to international trade in cultural objects, in: J.A.R. Nafziger, T.B. Stoel (eds.), Handbook on the Law of Cultural Heritage and International Trade, Cheltenham 2014, pp. 589-622.

${ }^{20}$ As of April 2018.

${ }^{21}$ Cf. Auction sales turnover 2002 / weight by country. Art Market Trends. Tendencies du marche de l'art, Artprice 2002-2014, p. 6, available at: https: / / imgpublic.artprice.com/pdf/trends2002.pdf (access: 26.04.2018).

${ }^{22}$ See more: W. Kowalski, op.cit, p. 78.

${ }^{23}$ However, already in 1998 the question was raised by senators in France, see: Question orale ${ }^{\circ}$ 0338S de M. Daniel Hoeffel (Bas-Rhin - UC), le JO Sénat du 22/10/1998, p. 3940.

${ }^{24}$ Cf. L. Prott, The UNIDROIT Convention on Stolen or Illegally Exported Cultural Objects - Ten Years On, "Uniform Law Review" 2009, Vol. 14, Issue 1-2, p. 215-237, doi: https://doi.org/10.1093/ulr/14.1-2.215.

25 Ibidem, pp. 221. 
of the institution of the so-called commissaires-priseurs ${ }^{26}$, along with the global expansion of Anglo-Saxon cultural institutions, the debate over ratifying a new international instrument interfering with the traditional order of found fertile ground for fabricated conclusions. Apart from pointing out the exclusive approach to the international character of claims the Convention refers to, the art world has expressed anxiety that the ratification of the agreement would have destructive effects on the integrity of existing collections ${ }^{27}$. The non-retroactivity principle is clearly visible in the text of the Convention, however, it does not imply a tolerant approach to any illicit acts that might have happened prior to its entry into force $^{28}$. Interestingly, when in 2013, the Association for the Protection of Chinese Art in Europe (APACE) were filing a motion to block the (infamous) sale of the two bronze animal heads at Christie's, the lawyers wanted to pertain to the 1995 convention and the clearly formulated obligation of the possessor of a stolen object to return $\mathrm{it}^{29}$. However, as the Convention had not been ratified by France, the principle was not binding, on the other hand, even if it had been, it would not have acted retroactively. The claims referred to the breach of confidentiality in the dealer-client relationship ${ }^{30}$, however, the gaps in tracking sales and exercising due diligence attract criminal activity. In other countries, such as Poland, recent years have been prolific in terms of new regulations approaching standardisation of market operations ${ }^{31}$, therefore raising the moral obligation to provide a clear and trust-worthy market.

${ }^{26}$ See: E. Lazzaro, N. Moureau, Auctioneers vs. commissaires-priseurs: The carnival mirror of profession regulation in the international art market, "The European Journal of Comparative Economics" 2013, Vol.10, Issue 2, pp. 159-176.

27 L. Prott, op.cit., p. 217.

${ }^{28}$ M. Schneider, op.cit., p. 490.

29 A. Wallace, A.L. Bandle, M.A. Renold, Case Two Bronze Animal Heads China and Pierre Bergé, Platform ArThemis, 2013, available at: https://plone. unige.ch/art-adr/cases-affaires / two-bronze-animal-heads-2013-china-andpierre-berge/case-note-two-bronze-animal-heads (access: 28.04.2018).

${ }^{30}$ L. Prott, op.cit., p. 217.

${ }^{31}$ E.g. The amendments to the Act of July 23, 2003 on monument protection ("Journal of Laws" of 2014, item 1446, as amended) [Ustawa $z$ dnia 23 lipca 2003 r. o ochronie zabytków i opiece nad zabytkami (Dz.U. z 2014 r. 
Poland has been a State party to the 1970 UNESCO Convention since 1974. However, as the 1970 Convention provides only an outline of recommendations, the UNIDROIT Convention model would be a more effective and universal solution ${ }^{32}$. As of today, the 1995 Convention is not ratified by Poland. Since the 2014 EU Directive does not apply to cross-continental trade in terms of establishing common grounds for transfer or restitution of cultural property, the ratification of the 1995 Convention could prove to fill the gaps. The ratification of the 1995 convention is recommended in the 2014 directive $^{33}$. It may lead to completing one of the main goals of the Convention i.e. facilitating the cultural exchange and cooperation, thus strengthening the partnership in art trade and, subsequently, a development of the market and a complimentary provenance research practices as per the condition of executing due diligence, in consequence, building trust in international relations.

\section{Conclusion}

The 1995 Convention provides a number of modern, flexible solutions that might influence the unification of the approach to

poz. $1446, \mathrm{z}$ późn. $\mathrm{zm}$.)] including the introduction of sale register books to art business entities.

${ }^{32}$ P. Gwoździewicz, Przedawnienie roszczeń o zwrot dóbr kultury, in: W. Kowalski, K. Zalasińska (eds.), Rynek sztuki: aspekty prawne, Warszawa 2011, p. 225.

33 "In its Conclusions on preventing and combating crime against cultural goods adopted on 13 and 14 December 2011, the Council recognised the need to take measures in order to make preventing and combating crime concerning cultural objects more effective. It recommended that the Commission support Member States in the effective protection of cultural objects with a view to preventing and combating trafficking and promoting complementary measures where appropriate. In addition, the Council recommended that the Member States consider the ratification of the Unesco Convention on the Means of Prohibiting and Preventing the Illicit Import, Export and Transfer of Ownership of Cultural Property signed in Paris on 17 November 1970, and the UNIDROIT Convention on Stolen or Illegally Exported Cultural Objects signed in Rome on 24 June 1995". 
exercising due diligence in art transactions and cultural exchange in general. On the other hand, conventions which tremendously impact the rules or practice are much more demanding and require establishing a new legislation. Despite causing a significant objection in France, the ratification of the 1995 UNIDROIT Convention in Poland might influence the reputation of art business entities and as Poland has recently adopted new provisions on the art market, the dynamism in legislation might create beneficial conditions for considering supplemental agreements supporting the internationalisation of cultural activity and the art business in particular. Moreover, in the times of favouring looted art loans to their countries of origin instead of proper restitution ${ }^{34}$, the question of establishing a common understanding of diligent and moral cultural cooperation and art transactions on the market remains open for further discussion.

\section{STRESZCZENIE}

Należyta staranność na rynku sztuki.

Analiza znaczenia Konwencji UNIDROIT o skradzionych lub nielegalnie wywiezionych dobrach kultury z 1995 r.

Konwencja UNIDROIT o skradzionych lub nielegalnie wywiezionych dobrach kultury z 1995 r., wypracowana przez Międzynarodowy Instytut Unifikacji Prawa Prywatnego (UNIDROIT), jest zbiorem podstawowych zasad dotyczących zachowania, restytucji i zwrotu dóbr kultury. Genezą jej powstania jest m.in. potrzeba ujednolicenia definicji terminu nabywcy w dobrej wierze, chronionego w wielu krajach. Ocena zachowania należytej staranności na rynku sztuki stanowi podstawę ustalenia okoliczności zakupu, zatem kroki podjęte w celu jej zapewnienia powinny wynikać ze stosowania ujednoliconego zbioru zasad postępowania, jakim jest konwencja. Praktyczne zastosowanie tych rozwiązań musi jednak zostać poddane

${ }^{34}$ See: J. Pes, V\&A Director Rules Out Macron-Style Return of Africa's Looted Treasure. But Tristram Hunt says loans are on the table as Ethiopian treasures looted after the Battle of Maqdala go on show in London, April 5, 2018, available at: https://news.artnet.com/art-world/va-director-rules-out-macron-stylereturn-of-africas-looted-treasure-1260059 (access: 28.04.2018). 
analizie w związku ze zróżnicowaniem rynku międzynarodowego. Niniejszy artykuł stanowi wprowadzenie do analizy możliwych przeszkód przy zastosowaniu uwspólnionego rozumienia należytej staranności w kontekście międzynarodowym.

Słowa kluczowe: należyta staranność; UNIDROIT; rynek sztuki; restytucja; dobra kultury

\section{SUMMARY}

Due Diligence and the Art Market. Assessing the Impact of the 1995 UNIDROIT Convention on Stolen or Illegally Exported Cultural Objects

The International Institute for the Unification of Private Law (UNIDROIT) has established a framework for the preservation, restitution, and return of cultural objects by means of drafting the 1995 Convention on Stolen or Illegally Exported Cultural Objects. The Convention reflects the necessity of common grounds for understanding the term of a bona fide purchaser, which is protected in many countries. The assessment of exercising due diligence on the art market plays a key role in determining the nature of an acquisition, therefore the measures undertaken should stem from a shared "toolbox", i.e. the Convention. However, since art markets vary from country to country, the practicality of implementing the abovementioned solutions needs to be assessed. The following study provides an overview of potential obstacles and possibilities when a common notion of due diligence on the art market is considered in multiple locations.

Keywords: due diligence; UNIDROIT; art market; restitution; cultural objects

\section{BIBLIOGRAPHY}

Bandle A.L., Theurich S., Alternative Dispute Resolution and Art-Law A New Research Project of the Geneva Art-Law Centre, "Journal of International Commercial Law and Technology” 2011, 6(1).

Cornu M., Engaging the European Art Market in the fight against the illicit trafficking of cultural property. Study for the capacity-building conference, 20-21 March 2018. Fighting Illicit Trafficking in Cultural Objects, 
Searching for Provenance and Exercising Due Diligence in the European Union, (n.p.) 2017.

Elgammal A., Kang Y., Leeuw M.D., Picasso, Matisse, or a Fake? Automated Analysis of Drawings at the Stroke Level for Attribution and Authentication, (n.p.) 2017.

Elliott M.A., Schmutz V., World heritage, “The Wiley-Blackwell Encyclopedia of Globalization" 2017.

Fiorentini, F., A legal pluralist approach to international trade in cultural objects, in: J.A.R. Nafziger, T.B. Stoel (eds.), Handbook on the Law of Cultural Heritage and International Trade, Cheltenham 2014.

Giroud, S., Boudry, Ch., Art Lawyers' Due Diligence Obligations: A Difficult Equilibrium between Law and Ethics, "International Journal of Cultural Property” 2015, Volume 22, Issue 2-3.

Gwoździewicz, P., Przedawnienie roszczeń o zwrot dóbr kultury. In: W. Kowalski, \& K. Zalasińska (eds.), Rynek sztuki: aspekty prawne, Warszawa 2011.

Hook, P., Rogue' Gallery: A History of Art and its Dealers, London 2017.

Kowalski, W., The road to the 1995 UNIDROIT Convention and its basic solutions, "Santander Art and Culture Law Review" 2015, Volume 1.

Lazzaro, E., Moureau, N., Auctioneers vs. commissaires-priseurs: The carnival mirror of profession regulation in the international art market, "The European Journal of Comparative Economics” 2013, Volume 10, Issue 2.

Prott, L., The UNIDROIT Convention on Stolen or Illegally Exported Cultural Objects - Ten Years On, "Uniform Law Review" 2009, Volume 14, Issue $1-2$.

Reeves, V.K., Establishing Authenticity in French Law, in: R.D. Spencer (ed.), The Expert versus the Object: Judging Fakes and False Attributions in the Visual Arts, New York, NY 2004.

Renold, M.A., Stolen Art: The Ubiquitous Question of Good Faith. In Resolution of Cultural Property Disputes, edited by The International Bureau of the Permanent Court of Arbitration, The Hague 2013.

Schneider, M., UNIDROIT Convention on Stolen or Illegally Exported Cultural Objects: Explanatory Report/Convention d'UNIDROIT sur les biens culturels volés ou illicitement exportés: rapport explicatif, "Uniform Law Review" 2001, Volume 6, Issue 3.

Wallace, A., Bandle, A.L., Renold, M.A., Case Two Bronze Animal Heads China and Pierre Bergé, 2013.

Zalasińska, K., Dobra wiara jako przesłanka ochrony nabywców kradzionych dzieł sztuki. Wybrane zagadnienia, "Palestra" 2010, Issue 5-6. 
